\title{
Ambiguous symbols: why there were no figurines in Neolithic Britain
}

\author{
Julian Thomas \\ School of Arts, Histories and Cultures, University of Manchester, UK \\ Julian.Thomas@manchester.ac.uk
}

\begin{abstract}
In this paper I discuss the scarcity of representational art, and particularly of representations of the human body, in Neolithic Britain, in contrast with the Neolithic of south-east Europe. My suggestion is that this contrast can be linked with differing notions of personal identity and bodily integrity. In later Neolithic Britain, a complex mode of non-representational decoration developed, which elaborated the practice of making reference to absent persons and things by using deliberately ambiguous motifs, which connected past and present as well as remote locations.
\end{abstract}

IZVLEČEK - V tem članku razpravljam o redkosti reprezentativne umetnosti, predvsem o redkosti upodobitev človeškega telesa v neolitiku Britanje, kar je v nasprotju z neolitikom Jugovzhodne Evrope. Menim, da lahko to nasprotje lahhko povežemo z različnimi predstavami o osebni identiteti in telesni integriteti. V poznnoneolitski Britaniji, se je razvila kompleksna oblika nereprezentativnih dekoracij. Na ta način so z uporabo namensko dvoumnih motivov, ki so povezovali preteklost in sedanjost kot tudi oddaljena mesta, izpopolnili običaje povezovanja z odsotnimi osebami in predmeti.

KEY WORDS - Neolithic; figurines; symbols; ritual practice

\section{INTRODUCTION: MISSING BODIES}

At a very high level of generality, there are interesting contrasts between the more overtly symbolic forms of material culture found in the Neolithic of Atlantic north-west Europe and those of the Balkan peninsula. Potentially, these can provide the startingpoints for an investigation of how material symbols were deployed and manipulated in these two regions. In south-east Europe one of the most distinctive elements of the Neolithic archaeological record is the presence of numerous human figurines, principally made of fired clay. In the British Isles, however, representations of the human body are extremely rare. There is, for example, the so-called 'Goddolly', made of ash wood and recovered from the wooden 'Bell A' track-way at Westhay in the Somerset levels (Coles 1968.276). This hermaphroditic figure with a head, protruding breasts and a phallus had been incorporated into the fabric of the trackway itself, and dates to 3913-3370 BC at the 2 sigma level of confidence (GaK-1600).
There are also somewhat unconvincing human torsos sculpted from chalk, and recovered from the causewayed enclosures of Windmill Hill and Maiden Castle (Piggott 1954.88). And finally, there is the bulbous female figurine that A. L. Armstrong retrieved from Pit 15 at the later Neolithic flint mine of Grimes Graves in Norfolk. Debate still continues over whether or not this find was genuine, or a hoax perpetrated by the workmen on the site, or perhaps even by Armstrong himself (Russell 2000.42). The chalk figure has no parallel, and would have been easy to fake, yet the platform of packed flint and group of antler picks with which it was associated do suggest a genuinely special context. Perhaps significantly, Neolithic Britain has produced more carvings of body parts than of whole bodies. Chalk phalluses are known from Windmill Hill and Grimes Graves, as well as the long barrow at Thickthorn Down, the flint mines of Blackpatch in Sussex, and the later Neolithic henge enclosures of Mount Pleasant and 
Maumbury Rings (Piggott 1954.88; Wainwright 1979.167; Bradley 1976.25).

In the Balkan context, Douglass Bailey has recently suggested that the emergence of clay figurines can be connected with the development of the 'built environment' of the tell settlements, from around 6500 BC onwards (Bailey 2005.4). Bailey's argument is that in this region the adoption of domesticated plants and animals was of less significance than the development of a constructed life-space, within which people lived in dense aggregations. Under these circumstances, the negotiation of personal identity and household composition would have become major preoccupations, as indeed would the resolution of disputes between persons or groups. In the earliest Balkan Neolithic settlements, burials were deposited beneath and between the houses, but from around $5500 \mathrm{BC}$ onwards funerary practice was often removed to extramural cemeteries. Consequentially, we have the development of two parallel contexts in which the human body was displayed and manipulated. For while figurines became more complicated in their manufacture and decoration, and possibly became more numerous over time, their use continued to be concentrated in the house and its surroundings. Only in the Hamangia area of the lower Danube were figurines routinely deployed as grave goods. By contrast, mortuary rites focused on the body increasingly made use of objects and substances such as metalwork, which are rarely found on settlements. We might say that within these two contexts the body was becoming elaborated, in rather different ways.

Bailey describes these developments in the Balkan Neolithic and Copper Age as representing a new 'politics of the human body' (Bailey 2005.197). What is interesting is that although as time proceeded there came to be a concern with the breaking and fragmentation of figurines (see Chapman 2000.68-79), the human body was both represented and deposited in the grave as an integral whole, around which other objects could be arranged. It seems plausible that this is indicative of a particular conception of personhood, in which people were at once the components of household and community units, and the vehicles of alliances, prestige, and the distribution of wealth. The representation of the body in miniature enabled reference to be made to particular persons in multiple spheres of conduct, possibly enabling different aspects of their identity to be elicited as circumstances required. Figurines are a much less common component of the Neolithic north of the Alps and Carpathians, and it is tempting to relate this contrast to the very particular inter-generational commitment to specific residential locations that characterised the Balkan Neolithic. The longevity of Bandkeramik settlements in central Europe, by comparison, took a rather different form. Here, clusters of houses slowly crept across the loess plateaus, each building being replaced adjacent to the original, rather than on precisely the same spot (e.g. Lüning 1982.19).

However, it is in the Atlantic zone, and in the British Isles in particular, that the scarcity of representations of the integral human body coincided with a quite different conception of the person, manifested in mortuary practice. While there is great variability in the evidence available to us, and while that evidence presumably only relates to a minority of the Neolithic population, one of the principal themes in British early Neolithic funerary activity was the disarticulation and disaggregation of the body (Thomas 2000). In both the timber mortuary structures which preceded the construction of earthen long barrows and in a variety of forms of megalithic tombs, the initial deposition of complete bodies was followed by a lengthy process of re-arrangement following the rotting away of the flesh. In some cases, this involved the selection and re-grouping of body parts, so that skulls were sometimes lined up at the foot of an orthostat, while long-bones were often stacked or bundled (Saville 1990.80). In some cases, individual bones may have been introduced to tombs or mortuary structures from elsewhere, whether from other structures or as the products of practices of excarnation. In more cases, the indication is that skeletal elements had been removed from mortuary deposits, for use in other contexts. And indeed, single bones or groups of bones are often encountered in the ditches of causewayed enclosures, in pit deposits, in caves, in rivers, and in a variety of other locations. Moreover, there are indications that body parts may sometimes have been curated for extensive periods before they were finally deposited. In these circumstances, it may be appropriate to think of megalithic tombs and long barrows less as communal cemeteries, and more as places of transformation, through which human bodies passed in the process of becoming something different (Lucas 1996. 102).

In the context of the present discussion, the significant point is that in Neolithic Britain human beings were understood as partible, at least in death (see Fowler 2004.25-31). That is to say, they were not 
individual minds or spirits bounded within an undivided body, but composed of body parts of substances that were capable of separation and circulation. In the early Neolithic landscape the dead were ubiquitous, and the body parts of the dead generations passed from place to place, and perhaps from person to person. Under these circumstances human identity may have been understood as fluid, protean and transitory, and less anchored in place and continuity than in south-east Europe. Descent and the continuous inhabitation of a fixed location may have been less significant than the maintenance of ties of kinship and affinity between dispersed and in some cases mobile communities. Consequentially, the representation of the person in the form of an entire body may not have been a cultural priority, and indeed the fashioning of objects in the shape of body parts such as the genitals is comprehensible in there terms. Certain of the attributes or powers of the person may have been understood as separable from the body as a whole, and to have been capable to introduction into remote contexts. In this way, it may have been possible to extend the presence of the person, and their effects, across space and time.

\section{ARBITRARY MEANINGS}

While contrasting notions of personal identity go some way toward explaining the specific character of material symbolism in Neolithic Britain, this is only part of the answer. A largely non-representational suite of Neolithic material culture was established in Britain at around $4000 \mathrm{BC}$, but in the period after $3000 \mathrm{BC}$ this range of artefacts was significantly elaborated, resulting in both a wider range of artefact types and an enhanced role for decoration. This process of diversification and increased investment of effort affected objects with readily identifiable functions, such as pottery and stone tools, but it is also seen in the emergence of a range of new artefact types which defy any straightforwardly functional explanation. During the early 1980s, a series of innovative analyses brought these objects to greater archaeological prominence, by describing them as 'prestige goods', 'weapons of exclusion' or 'symbols of power' (Bradley 1984.46; Clarke, Cowie and Foxon 1985.11). These artefacts include stone and antler mace-heads, jet belt-sliders, bone pins, polished-edged flint adzes, carved stone balls, boar's tusk amulets and a variety of new flint arrowhead types, such as chisel-shaped and oblique forms. Alongside this greater material variability went an increase in the complexity and diversity of the depo- sitional practices in which these objects were deployed. The later Neolithic saw elaborate artefacts being placed in formal pit deposits, in single grave burials which gradually replaced the multiple burials of the earlier Neolithic, in hoards and 'closing deposits' inserted into megalithic tombs, in rivers, bogs and caves, and in new monument types such as henges and palisaded enclosures (Thomas 1999. Chapter 4).

Significantly, a sub-set of these new artefacts were decorated with a set of symbols which ultimately (but not exclusively) owed their inspiration to the decorative 'art' of the passage tombs of Ireland and western Britain (Bradley and Chapman 1986.131). So although there was a general increase in decoration in the later Neolithic, it remained non-representational in character. If anything, artefactual decoration became at once more ornate and more cryptic during the later Neolithic. If we return to the contrast between north-west and south-east Europe, it is instructive to consider the power and efficacy of non-representational but formalised symbols - symbols that constitute a kind of 'material language'. Victor Turner once argued that symbols make up the basic units of ritual practice, and that the most important feature of ritual symbols is that they are polyvalent, or multi-referential (Turner 1967.28). That is to say, they mean no one thing, but may condense a whole range of different meanings. Different aspects of this range of meanings may be drawn upon in different stages of a ritual performance. The consequence of this is that ritual practice can draw together a relatively limited set of objects into a consecrated space, and effectively manipulate the world in microcosm. Formal or geometrical designs are particularly suitable as ritual symbols, for while they may suggest many meanings, they ultimately represent no one thing. Their relationship to the world at large is an arbitrary one, and they may bring a whole range of associations and connotations to bear on any context of performance or interaction. Moreover, their arbitraryness and indefinable quality has the consequence that they require explanation or exegesis. As a result, the social position of being a person who is empowered to interpret these symbols is one of privilege, and their 'deeper' or more profound significance may only be revealed to a minority of people, or under specific conditions.

All of this applies to the symbolic material media of later Neolithic Britain. These were evidently used in a variety of transactions and performances that were ritualised in character, and they served to represent, 
connote or remind participants of qualities or phenomena in the wider world. Some of these may have been the qualities or powers of particular persons, or of supernatural beings. Perhaps the most significant aspect of all was the referentiality of these symbols; the way that they established connections between remote contexts, both spatially and temporally. It is this theme of referentiality that we will concentrate on in the remainder of this contribution.

\section{Symbolic connections}

We can begin with megalithic art. In Iberia and Brittany, the decoration on menhirs and passage tombs includes representational devices as well as geometric figures, and these include animals, human figures, axes and bows (Shee Twohig 1981.13-92). In Britain and Ireland these motifs are absent. Whether this is a consequence of an overall change in the character of megalithic art over time or of local preference is unclear, but it does mean that in Ireland and Britain, passage tomb art took a form that was not self-evident, and which may have formed an active component of an array of ritual symbols used inside these monuments. Anna Brindley (1999) has recently drawn attention to the rather complicated chronological relationship between passage tomb art and the mobiliary media that draw on it as a source of symbols. Brindley notes that the passage tombs of Ireland were constructed prior to $3000 \mathrm{BC}$, and that an earlier style of decoration, which she slightly misleadingly calls 'depictive' is probably contemporary with their building, as it extends onto the backs of stones and the parts of stones which extend below ground level. The implication of this is that the decoration must have been executed before the stones were put in place. A later, 'plastic' style of ornamentation, characterised by area pecking, was probably added to the stones of some of the larger tombs in the Boyne valley at a later date, after their construction (Brindley 1999.135).

Interestingly, it is the earlier style of decoration that provided the motifs that were transferred to a variety of portable artefacts, most notably Grooved Ware. Grooved Ware was a style of pottery that was used throughout Britain and Ireland in the later Neolithic, predominantly occurring in 'special' contexts such as the Wessex henges, formal pit deposits, and palisaded enclosures (Cleal 1999.4). Chronologically it must have overlapped with the 'depictive' passage tomb art for only a very short period at the end of the fourth millennium BC. Moreover, the earliest Grooved Ware is presumed to have devel- oped in the north of Scotland, and particularly in Orkney. This is quite remote from the 'heartland' of decorated passage tombs in Ireland, and suggests a process of translation or displacement, in which symbols which have acquired their significance in one context are deployed in a different way in another region, while still bringing some of their connotations with them.

The specific motifs transferred from megalithic art to Grooved Ware include chequer-boards composed of alternately filled squares and triangles, lattices of crossing lines, conjoined spirals and lozenges, running lozenges, and spirals placed on a background of horizontal lines. As Brindley points out, this last motif is drawn specifically from the carved stone basins which held cremated human remains at passage tombs such as Knowth, and was faithfully replicated on Grooved Ware vessels such as one recovered from the entrance of the southern timber circle in the Wiltshire henge of Durrington Walls (Brindley 1999.136; Wainwright and Longhworth 1971.140-1). Yet the Durrington pot must be around five hundred years later than the Knowth basin, as the radiocarbon dates for the southern circle cluster a little after $2500 \mathrm{BC}$.

The possibility that Grooved Ware decoration, from its inception, referred to distant or absent contexts is intriguing, because it fits so well with what we know about the use of Grooved Ware. Grooved Ware pits were often located in relation to places which had a long history of inhabitation, such as long-abandoned timber buildings. For instance, at Yarnton in the Upper Thames valley, a large wooden hall dating to the earliest Neolithic contained a heath and a pit containing Grooved Ware, which produced a radiocarbon date approximately a thousand years later than that of the building (Hey, Mulville and Robinson 2003.81). Similarly, at Littleour on Tayside in Scotland, a rectilinear timber structure, which may not have been roofed but which possibly referred to a domestic building in some way, also contained a Grooved Ware pit. This, again, seemed to be some hundreds of years younger than the original building (Barclay and Maxwell 1998.58). These deposits can be compared with the situation at the palisaded enclosure at Dunragit in south-west Scotland, excavated by the present author between 1999 and 2002, where sherds of Grooved Ware were placed into the craters left behind by the removal of the decaying posts of the inner timber circle (Thomas 2004.104). Furthermore, at the Durrington Walls henge it is possible that the greatest density of pottery in the south- 
ern circle was deposited in re-cuts, dug into the tops of the post-holes after the wooden uprights had rotted out (Wainwright and Longworth 1971.207). It is possible that some of the irregularities identified in the dating of Grooved Ware contexts in southern Britain can be attributed to the referential character of much Grooved Ware deposition, which may have taken place long after the principal occupation or use of sites and structures. In the case of the henge monuments of Wessex, Garwood (1999.154) has argued that a change of practice can be identified over time, with deposition in the circular timber structures being later than that in the surrounding ditches. It may be that this pattern simply reflects the reality that deposition in timber circles only took place once the uprights had rotted out, a process that might have taken two centuries or more. The implication would be that the Grooved Ware deposits in the tops of the post-holes at sites like Durrington Walls were a means of celebrating and remembering the timber structure that had once stood there, but which was now no longer present.

\section{Commemoration and reference}

What all this indicates is that while Grooved Ware was used in episodes of consumption and perhaps feasting, much of this was actually commemorative in character. It may have represented ritual activity conducted on already ancient or derelict sites, which sought to celebrate, and establish links with, the past. In the same way, the use of the particular set of motifs on Grooved Ware pottery served to establish connections with the distant past and far-away places. Interestingly, late Neolithic post or pit structures associated with Grooved Ware have been found outside the large Irish passage tombs of Knowth and Newgrange, and it is arguable that the activities that took place in these locations might have commemorated or laid claim to the now ancient tombs (Eogan and Roche 1999.105). However, the Grooved Ware deposited in these structures is comparatively austere in its decoration, and lacks the symbols found on pottery elsewhere (Brindley 1999.31). Perhaps the use of such symbols on portable artefacts was inappropriate in the immediate vicinity of the decorated passage tombs themselves.

This notion of appropriateness draws our attention to the specificity of the contexts in which decorated objects were used in the later Neolithic. For 1977). while passage-tomb motifs were 'translated' onto Grooved Ware pottery, they also occur on a variety of other forms of material culture. Yet importantly, these different artefact types are seldom found in the same contexts, or even on the same site. It appears that although motifs might 'migrate' between different contexts and locations, specific artefact types were judged apposite for different sets of practices or locations. The motifs or symbols thus appear to have formed an overarching system or 'language', which linked spatially and temporally remote locations, providing reminders of events that had happened or were happening elsewhere, while still keeping those different contexts separate from each other.

That these objects were not prestige goods, in the full sense of artefacts whose production and circulation could be controlled by the powerful, seems to be demonstrated by the existence of a small number of carved chalk plaques, like those from King Barrow Wood near Stonehenge and Kilham in East Yorkshire (Vatcher 1969; Harding 1988; Varndell 1999). These objects carry the lattice, ladder, zig-zag and decorated-cordon motifs of Grooved Ware, yet they were made from a ubiquitous raw material with only moderate levels of skill. The King Barrow Wood plaques were deposited with some formality in a pit that also contained sherds of Grooved Ware, and in this case it seems that it was the symbols themselves, rather than the medium that bore them, that were of importance. The same argument applies to Grooved Ware pots themselves, for petrological analysis demonstrates that they were rarely traded over any distance, although individual pots were often curated, to judge by the presence of repair-holes used to bind breaks together (Cleal 1988).

While the chalk plaques were sometimes found alongside Grooved Ware, the same is not generally true of the carved stone balls of north-east Scotland. Indeed, outside of Orkney these are rarely found in

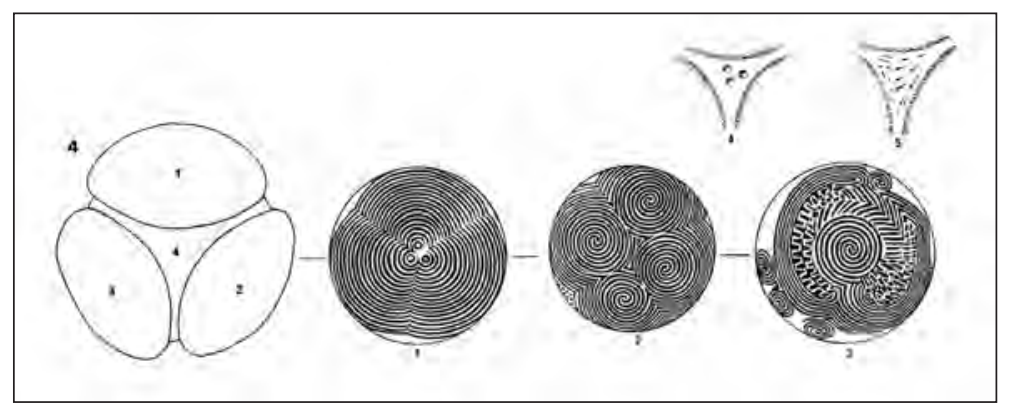

Fig. 1. The carved stone ball from Towie, Scotland (After Marshall 
any archaeological context at all, and have generally been isolated finds (Marshall 1977.55). The minority of these objects that are decorated carry spirals, chevrons, zig-zags and concentric triangles (Fig. 1). Their worn surfaces suggest that they have been extensively handled, and this indicates that they carried Grooved Ware symbolism into a variety of contexts of interpersonal contact in which pottery vessels were not used. By contrast, mace-heads of stone and antler sometimes carry the lozengelattice motif associated particularly with the Woodlands style of Grooved Ware (Roe 1968.149), although one antler mace recovered from the

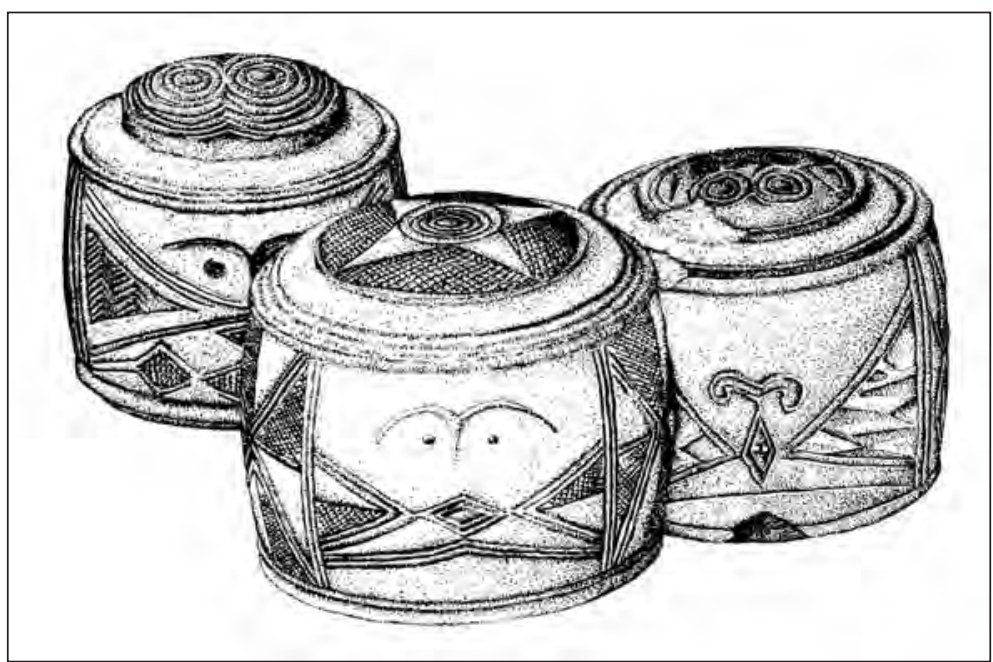

Fig. 2. The carved chalk drums from Folkton, Yorkshire (drawing by Rick Peterson).
River Ouse at Garboldisham bears a conjoined spiral design (Edwardson 1965). Unlike carved stone balls, mace-heads are occasionally found as grave goods (as with one of the cremations at Dorchester on Thames. Atkinson, Piggott and Sandars 1951. 116). Again, this suggests a particular element of Grooved Ware symbolism being introduced into a spe-

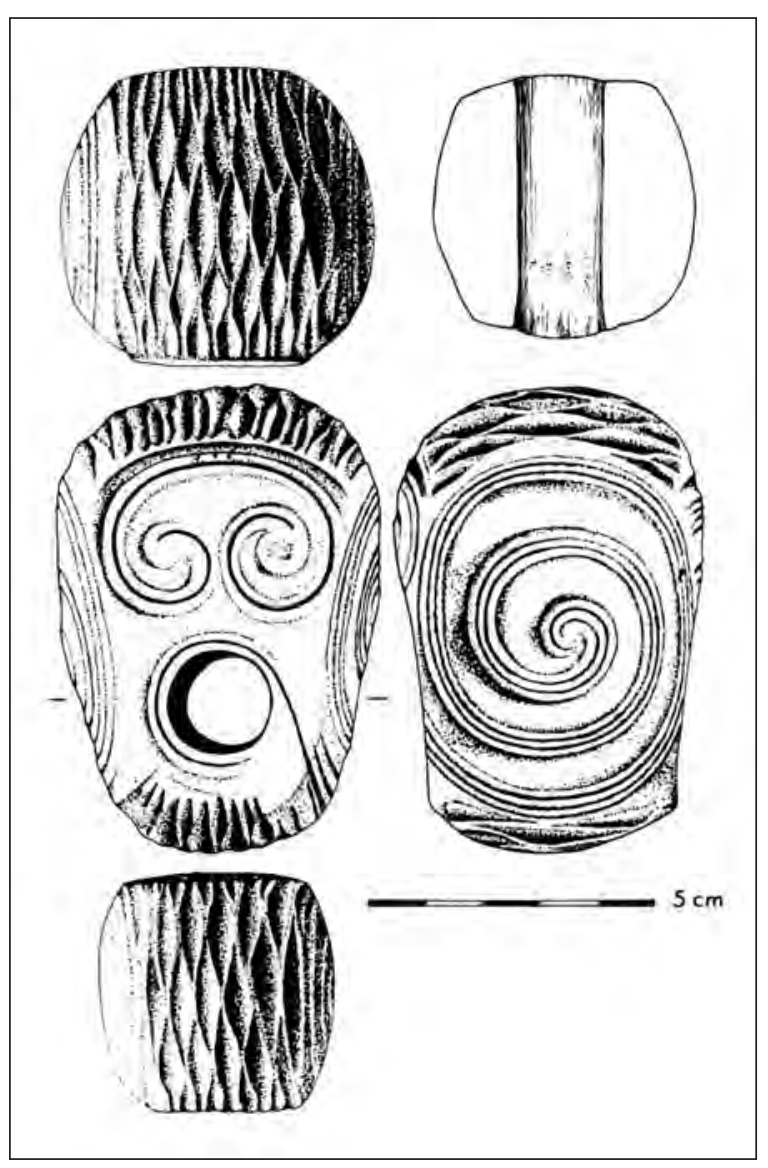

Fig. 3. Flint mace-head from Knowth, Co. Meath, Ireland (After Eogan 1986). cific setting, for Grooved Ware itself is very rarely found in any mortuary context other than the chambered cairns of Orkney.

Also from a funerary setting came the three spectacular chalk drums from Folkton in East Yorkshire (Fig. 2). These were found in the grave of an adolescent beneath a round barrow, which also contained a further seven burials, two of them associated with Beaker vessels (Kinnes and Longworth 1985.115б). The Beaker association suggests that like the Durrington Walls spiral pot, the Folkton Drums must be hundreds of years later than the megalithic art that provided their ultimate inspiration. In addition to concentric circles, filled triangles, lattices, chevrons and grooves, the drums carry a motif that some have chosen to interpret as a pair of eyes and an eyebrow (Longworth 1999.80). But again, this is ambiguous, and like all ritual symbols it is open to a variety of interpretations.

Individual later Neolithic assemblages and objects can sometimes show startling similarities in terms of their decoration. For instance, a fine flint mace-head came from the entrance to the right-hand recess of the eastern tomb inside the mound at Knowth in Ireland (Eogan 1986.141) (Fig. 3). The two butt-ends of the mace are covered with a lozenge-mesh, characteristic of the 'Maesmore' group of stone mace-heads (Roe 1968.149). Although, as we have noted, maceheads including decorated crown antler examples are known from funerary contexts (Simpson 1996. 301), this is less often the case with Maesmore maces. On either side of the Knowth mace is a single spiral, and the upper faces has a motif composed of two conjoined spirals. It is difficult to give a pre- 


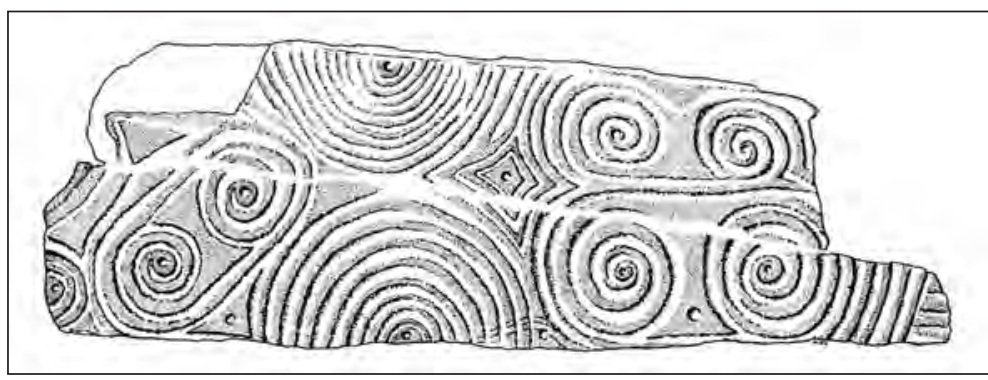

Fig. 4. Carved stone from the chambered tomb at Pierowall Quarry, Westray, Orkney (After Sharples 1984).

cise date to the object, but its recovery from the old ground surface might suggest that it is contemporary with the use of the tomb, at around $3000 \mathrm{BC}$. The conjoined spiral motif finds a very close parallel in the decorated stone (one of three) from the destroyed megalithic tomb at Pierowall Quarry on the Orkney island of Westray (Sharples 1984.82) (Fig. 4). This might be roughly contemporary with the Knowth tomb, or perhaps a little later (ibid.

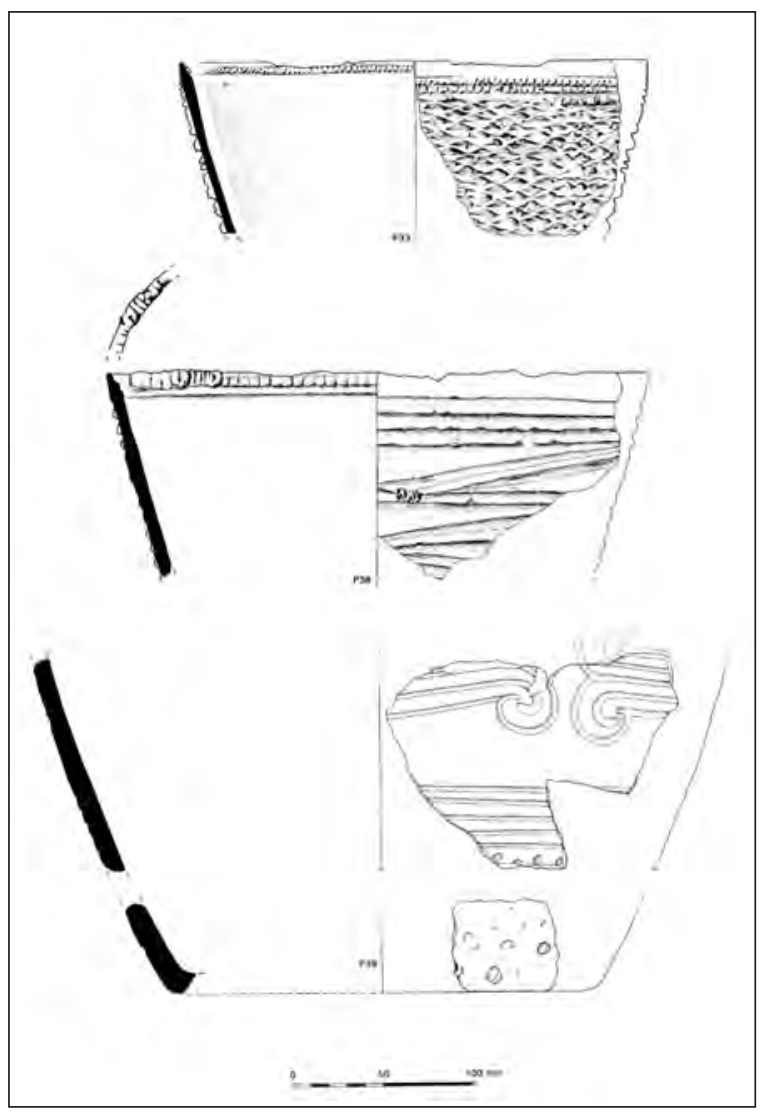

Fig. 5: Grooved Ware assemblage from Pit 3196, Barrow Hills, Oxfordshire (After Barclay and Halpin 1999).
118). But much later in date is Pit 3196 at Barrow Hills in Oxfordshire, which contained three Grooved Ware vessels (Barclay and Halpin 1999. 198). Its radiocarbon determination, 2570-2030 BC (BM-2706), places it toward the end of the Neolithic period. Yet the pottery vessels combine the lozenge-mesh design with a grooved-cordon motif, the terminals of which are effectively conjoined spirals (Fig. 5). The Barrow Hills Grooved Ware assemblage deploys very much the same combination of motifs as the Knowth mace-head, perhaps more than half a millennium earlier.

\section{CONCLUSION}

These examples of the later Neolithic use of decorative media are dispersed over considerable expanses of space and time. The same motifs occur across Britain and Ireland, and over hundreds of years. It is conventional to point to the power of tradition in maintaining ways of making and decorating objects over the generations. But here it may be that something more specific and more compelling was at work. The passage tomb/Grooved Ware suite of symbols was explicitly used to contextualise isolated acts of consumption and deposition, linking them to a past that was to be venerated and drawn into the present, and to distant places whose very remoteness afforded them a mythic quality. These symbols had associations that were fully understood, but their meanings were ambiguous and multiple, and that ambiguity or polyvalence was the source of their efficacy as tools in ritual practice. A symbolic system in which each symbol had a single, fixed significance would have been inflexible. Ambiguous, abstract motifs could be both allusive and referential, establishing connections between contexts which none the less required a degree of explanation. They were used in practices which commemorated the past and drew attention to remote places. This was possible because in the earlier Neolithic a partible notion of personal identity and a lack of emphasis on the representation of the whole human body had facilitated a practice of making absent persons and agencies present through the circulation of symbolic media. 


\section{REFERENCES}

ATKINSON R. J. C., PIGGOTT C. M. and SANDARS N. 1951. Excavations at Dorchester, Oxon. Ashmolean Museum. Oxford.

BAILEY D. W. 2005. Prehistoric Figurines: Representation and Corporeality in the Neolithic. Routledge. London.

BARCLAY A. and HALPIN C. 1998. Excavations at Barrow Hills, Radley, Oxfordshire. Volume 1: The Neolithic and Bronze Age Monument Complex. Oxford Archaeology Unit. Oxford.

BARCLAY G. J and MAXWELL G. S. 1998. The Cleaven Dyke and Littleour: Monuments in the Neolithic of Tayside. Society of Antiquaries of Scotland. Edinburgh.

BRADLEY R. J. 1976. Maumbury Rings, Dorchester: the excavations of 1908-13. Archaeologia 105: 197.

1984. The Social Foundations of Prehistoric Britain. Longmans. London.

BRADLEY R. J. and CHAPMAN R. 1986. The nature and development of long-distance relations in later Neolithic Britain and Ireland. In C. Renfrew and J. F. Cherry (eds.), Peer-Polity Interaction and SocioPolitical Change: 127-36.

BRINDLEY A. 1999. Sequence and dating in the Grooved Ware tradition. In R. Cleal and A. MacSween (eds.), Grooved Ware in Britain and Ireland: 13344.

CHAPMAN J. 2000. Fragmentation in Archaeology: People, Places and Broken Objects in the Prehistory of South Eastern Europe. London: Routledge.

CLARKE D. V., COWIE T. and FOXON A. 1985. Symbols of Power at the Time of Stonehenge. HMSO. Edinburgh.

CLEAL R. 1988. The occurrence of drilled holes in later Neolithic pottery. Oxford Journal of Archaeo$\log y$ 7: 139-45.

1999. Introduction: the what, where and when of Grooved Ware. In R. Cleal and A. MacSween (eds.), Grooved Ware in Britain and Ireland: $1-8$.
COLES J. 1968. A Neolithic God-dolly from Somerset, England. Antiquity 42: 275-77.

EDWARDSON A. R. 1965. A spirally decorated object from Garboldisham. Antiquity 39: 145.

EOGAN G. 1986. Knowth and the Passage Tombs of Ireland. Thames and Hudson. London.

EOGAN G. and ROCHE H. 1999. Grooved Ware from Brugh na Bóinne in its wider context. In R. Cleal and A. MacSween (eds.), Grooved Ware in Britain and Ireland: $98-111$

FOWLER C. 2004. The Archaeology of Personhood. Routledge. London.

GARWOOD P. 1999. Grooved Ware in southern Britain: chronology and interpretation. In R. Cleal and A. MacSween (eds.), Grooved Ware in Britain and Ireland: $145-76$.

HARDING P. 1988. The chalk plaque pit, Amesbury. Proceedings of the Prehistoric Society 54: 320326.

HEY G., MULVILLE J. and ROBINSON M. 2003. Diet and culture in southern Britain: the evidence from Yarnton. In M. Parker Pearson (ed.), Food, Culture and Identity in the Neolithic and Early Bronze Age. British Archaeological Reports IS 1117: 79-88.

KINNES I. A. and LONGWORTH I. H. 1985. Catalogue of the Excavated Prehistoric and Romano-British Material in the Greenwell Collection. British Museum. London.

LONGWORTH I. H. 1999. The Folkton Drums unpicked. In R. Cleal and A. MacSween (eds.), Grooved Ware in Britain and Ireland: 83-8.

LUCAS G. M. 1996. Of death and debt: a history of the body in Neolithic and Early Bronze Age Yorkshire. Journal of European Archaeology 4: 99-118.

LÜNING J. 1982. Research into the Bandkeramik settlement of the Aldenhovener Platte in the Rhineland. Analecta Praehistorica Leidensia 15: 1-29.

MARSHALL D. N. 1977. Carved stone balls. Proceedings of the Society of Antiquaries of Scotland 108: 40-72. 
PIGGOTT S. 1954. The Neolithic Cultures of the British Isles. Cambridge University Press. Cambridge.

ROE F. 1968. Stone mace-heads and the latest Neolithic cultures of the British Isles. In J. M. Coles and D. D. A. Simpson (eds.), Studies in Ancient Europe: 145-72.

RUSSELL M. 2000. Flint Mines in Neolithic Britain. Tempus. Stroud.

SAVILLE A. 1990. Hazleton North: The Excavation of a Neolithic Long Cairn of the Cotswold-Severn Group. English Heritage. London.

SHARPLES N. 1984. Excavations at Pierowall Quarry, Westray, Orkney. Proceedings of the Society of Antiquaries of Scotland 114: 75-126.

SHEE TWOHIG E. 1981. The Megalithic Art of Western Europe. Clarendon. Oxford.

SIMPSON D. D. A. 1996. 'Crown' antler maceheads and the later Neolithic in Britain. Proceedings of the Prehistoric Society 62: 293-309.

THOMAS J. S. 1999. Understanding the Neolithic. Routledge. London.
2000. Death, identity and the body in Neolithic Britain (the Curl Lecture for 1999). Journal of the Royal Anthropological Institute 6: 603-17.

2004. The later Neolithic architectural repertoire: the case of the Dunragit complex. In R. Cleal and J. Pollard (eds.), Monuments and Material Culture: Papers on Neolithic and Bronze Age Britain in Honour of Isobel Smith: 98-108.

TURNER V. W. 1967. The Forest of Symbols: Aspects of Ndembu Ritual. Cornell University Press. Ithaca.

VARNDELL G. 1999. An engraved chalk plaque from Hanging Cliff, Kilham. Oxford Journal of Archaeo$\log y$ 18: 351-55.

VATCHER F. de M. 1969. Two incised chalk plaques from Stonehenge bottom. Antiquity 43: 310-311.

WAINWRIGHT G. J. 1979. Mount Pleasant, Dorset; excavations 1970-71. Society of Antiquaries. London.

WAINWRIGHT G. J. and LONGWORTH I. 1971. Durrington Walls: Excavations 1966-1968. Society of Antiquaries. London. 